\title{
Expression and purification of human diacylglycerol kinase $\alpha$ from baculovirus-infected insect cells for structural studies
}

\author{
Daisuke Takahashi ${ }^{1}$, Fumio Sakane ${ }^{\text {Corresp. } 1}$ \\ ${ }^{1}$ Department of Chemistry, Graduate School of Science, Chiba University, Chiba, Japan \\ Corresponding Author: Fumio Sakane \\ Email address: sakane@faculty.chiba-u.jp
}

Diacylglycerol kinases (DGKs) are lipid kinases that modulate the levels of lipid second messengers, diacylglycerol and phosphatidic acid. Recently, increasing attention has been paid to its $\alpha$ isozyme (DGK $\alpha$ ) as a potential target for cancer immunotherapy. DGK $\alpha$ consists of the $\mathrm{N}$-terminal regulatory domains including EF-hand motifs and $\mathrm{Cl}$ domains, and the C-terminal catalytic domain (DGK $\alpha-C D)$. To date, however, no structures of mammalian DGKs including their catalytic domains have yet been reported, impeding our understanding on the catalytic mechanism of DGKs and the rational structure-based drug design. Here we attempted to produce DGK $\alpha-C D$ or a full-length DGK $\alpha$ using bacterial and baculovirus-insect cell expression system for structural studies. While several DGK $\alpha-C D$ constructs produced using both bacterial and insect cells formed insoluble or soluble aggregates, the full-length DGK $\alpha$ expressed in insect cells remained soluble and was purified to near homogeneity as a monomer with yields $(1.3 \mathrm{mg} / \mathrm{mL}$ per $1 \mathrm{~L}$ cell culture) feasible for protein crystallization. Following enzymatic characterization showed that the purified DGK $\alpha$ is in fully functional state. We further demonstrated that the purified enzyme could be concentrated without any significant aggregation, and characterized its secondary structure by circular dichroism. Taken together, these results suggest that the presence of $\mathrm{N}$-terminal regulatory domains suppress protein aggregation likely via their intramolecular interactions with DGK $\alpha-C D$, and demonstrate that the baculovirus-insect cell expression of the full-length form of DGK $\alpha$, not DGK $\alpha-C D$ alone, represents a promising approach to produce protein sample for structural studies of DGK $\alpha$. Thus, our study will encourage future efforts to determine the crystal structure of DGK, which has not been determined since it was first identified in 1959. 
1 Expression and purification of human diacylglycerol kinase $\alpha$ from baculovirus-infected

2 insect cells for structural studies

3

4 Daisuke Takahashi $^{1}$ and Fumio Sakane ${ }^{1 *}$

5

$6{ }^{1}$ Department of Chemistry, Graduate School of Science, Chiba University, 1-33 Yayoi-cho,

7 Inage-ku, Chiba, 263-8522, Japan

8

9 *Corresponding author:

$10 \quad$ Fumio Sakane

11 Department of Chemistry, Graduate School of Science

12 Chiba University

13 1-33 Yayoi-cho, Inage-ku, Chiba, 263-8522, Japan

14 Tel.: +81-43-290-3695

15

Fax: +81-43-290-3695

16

Email: sakane@,faculty.chiba-u.jp 


\section{ABSTRACT}

18 Diacylglycerol kinases (DGKs) are lipid kinases that modulate the levels of lipid second messengers, diacylglycerol and phosphatidic acid. Recently, increasing attention has been paid to its $\alpha$ isozyme (DGK $\alpha)$ as a potential target for cancer immunotherapy. DGK $\alpha$ consists of the Nterminal regulatory domains including EF-hand motifs and $\mathrm{C} 1$ domains, and the $\mathrm{C}$-terminal catalytic domain (DGK $\alpha-C D)$. To date, however, no structures of mammalian DGKs including

23 their catalytic domains have yet been reported, impeding our understanding on the catalytic 24 mechanism of DGKs and the rational structure-based drug design. Here we attempted to produce 25 DGK $\alpha-C D$ or a full-length DGK $\alpha$ using bacterial and baculovirus-insect cell expression system 26 for structural studies. While several DGK $\alpha-C D$ constructs produced using both bacterial and 27 insect cells formed insoluble or soluble aggregates, the full-length DGK $\alpha$ expressed in insect 28 cells remained soluble and was purified to near homogeneity as a monomer with yields (1.3 $\mathrm{mg} / \mathrm{mL}$ per $1 \mathrm{~L}$ cell culture) feasible for protein crystallization. Following enzymatic characterization showed that the purified DGK $\alpha$ is in fully functional state. We further demonstrated that the purified enzyme could be concentrated without any significant aggregation, and characterized its secondary structure by circular dichroism. Taken together, these results suggest that the presence of $\mathrm{N}$-terminal regulatory domains suppress protein aggregation likely via their intramolecular interactions with DGK $\alpha-C D$, and demonstrate that the baculovirus-insect cell expression of the full-length form of DGK $\alpha$, not DGK $\alpha$-CD alone, represents a promising approach to produce protein sample for structural studies of DGK $\alpha$. Thus, our study will encourage future efforts to determine the crystal structure of DGK, which has not been determined since it was first identified in 1959. 


\section{Introduction}

Diacylglycerol (DG) and phosphatidic acid (PA) are important signaling lipids and regulate a myriad of cellular events by modulating numerous signaling proteins (English, 1996; Stace \& Ktistakis, 2006; Griner \& Kazanietz, 2007; Almena \& Merida, 2011), including protein kinase C (PKC) isoforms (Newton, 1997; Parekh, Ziegler \& Parker, 2000; Griner \& Kazanietz, 2007) and Ras guanyl nucleotide-releasing protein (RasGRP) (Ebinu et al., 1998; Tognon et al., 1998) by DG, and mammalian target of Rapamycin (mTOR) (Ávila-Flores et al., 2005) and phosphatidylinositol (PI)-4-phosphate 5-kinase (PIP5K) (Moritz et al., 1992) by PA. DG kinases (DGKs), which was first identified in 1959 (Hokin \& Hokin, 1959), are a family of lipid kinase that regulates the intracellular levels of DG and PA by phosphorylating DG into PA (Sakane et al., 2007; Merida, Ávila-Flores \& Merino, 2008; Shulga, Topham \& Epand, 2011). Mammalian DGK consists of ten isozymes $(\alpha, \beta, \gamma, \delta, \eta, \kappa, \varepsilon, \zeta, \mathrm{l}$, and $\theta)$, classified in 5 subtypes featuring distinct regulatory domains and a conserved catalytic domain (Sakane et al., 2007; Shulga, Topham \& Epand, 2011), and each DGK serves as a key downregulator and upregulator for the DG and PA-mediated cellular signaling, respectively.

DGK $\alpha$ is the first-cloned DGK isozyme in mammals (Sakane et al., 1990) and has aminoterminal regulatory domains including EF-hand motifs and $\mathrm{C} 1$ domains, and a carboxyl-terminal catalytic domain (Fig. 1A). Recently, increasing attention has been paid to DGK $\alpha$ as a potential target for anti-cancer treatments including cancer immunotherapy (Dominguez et al., 2013; Purow, 2015; Sakane, Mizuno \& Komenoi, 2016; Liu et al., 2016; Noessner, 2017). Expression of DGK $\alpha$ has been reported to be upregulated in melanoma cells (but not in noncancerous melanocytes) (Yanagisawa et al., 2007), lymphoma (Bacchiocchi et al., 2005), hepatocellular carcinoma (Takeishi et al., 2012), breast cancer cells (Torres-Ayuso et al., 2014), and glioblastoma cells (Dominguez et al., 2013) where DGK $\alpha$ promotes cancer cell survival, proliferation, migration and invasion (Merida et al., 2017). siRNA knockdown of $D G K A$ or inhibition of DGK $\alpha$ by small molecule inhibitors for DGKs, R59022 and R59949, has detrimental effects on the proliferation of glioblastoma cells, melanoma, breast cancer, and cervical cancer cells (Yanagisawa et al., 2007; Dominguez et al., 2013). In T-lymphocytes, on the other hand, DGK $\alpha$ is appreciated as a critical attenuator for immune response. DGK $\alpha$ is highly expressed in T-cells and decreases membrane DG levels required for RasGRP1-dependent activation of the Ras-Erk pathway (Jones, 2002). Furthermore, in vitro and in vivo studies have 
71 uncovered that DGK $\alpha$ is responsible for T-cell hyporesponsive state known as anergy state 72 (Olenchock et al., 2006; Zha et al., 2006).

Using a high-throughput DGK assay, we have recently identified a novel DGK $\alpha$-selective inhibitor, CU-3, and revealed that this compound targets the catalytic domain of DGK $\alpha$ (Liu et al., 2016). Indeed, this compound not only induced the apoptosis of HepG2 hepatocellular carcinoma and HeLa cervical cancer cells as observed for other DGK inhibitors with lowerselectivity (Dominguez et al., 2013), but also enhanced the production of interleukin-2 in Jurkat T cells (Liu et al., 2016), illustrating a double-strike effect of DGKa inhibitors potentially utilized for cancer immunotherapy (Noessner, 2017). However, despite these biological and biomedical importance, no structure has been determined for the catalytic domains of any mammalian DGKs, thus impeding the detailed understanding of DGK catalytic machinery and substrate binding sites as well as the development and optimization of effective DGK $\alpha$ inhibitors.

One of the greatest challenges for the structure determination of DGK isozymes lies in producing enough and soluble proteins suitable for protein crystallization, as illustrated in previous studies (Takahashi et al., 2012; Petro \& Raben, 2013). Although intensive efforts have been made by Petro et al. (Petro \& Raben, 2013) to express and purify the full-length and catalytic domain $(\mathrm{CD})$ of porcine DGK $\alpha$ using bacterial expression system with expression-tags (glutathione S-transferase (GST), maltose binding protein (MBP), thioredoxin (TRX)) for solubility enhancement, all the expressed DGKa constructs formed inclusion bodies or soluble aggregates, likely due to the inability of bacterial translational and folding machineries. To overcome these problems, here we have taken advantage of the baculovirus-insect cell expression system to express a full-length DGK $\alpha$ in soluble form. DGK $\alpha$ expressed in the insect cells was then purified by a series of column chromatography, and the purified protein was found to be a monomer in solution. Successful purification of DGKa also allowed us to characterize enzymatic, inhibitory and structural properties of DGK $\alpha$ in vitro. Taken together, these results provide promising evidence that the baculovirus-insect cell expression system is better suited to produce DGK $\alpha$ for in vitro functional and structural studies. 


\section{Materials \& Methods}

\section{Bacterial expression and purification of DGKa-CD}

103 Multiple-constructs approach with different N- and C-terminal boundaries (Gräslund et al., 104 2008), and several N-terminal fusion-tags (GST, MBP, and small ubiquitin-like modifier

105 (Sumo)) was applied for bacterial expression of DGK $\alpha-C D$.

106 To prepare GST-fused constructs, the DNA sequences of DGK $\alpha$-CD (S332-G722,

107 D344-G722, D369-G722, S332-S735, D344-S735, D369-S735,) flanked by BamHI and SalI

108 restriction sites were amplified by PCR from the full-length cDNA for human DGKa, inserted

109 into a pGEX-4T-2 vector (GE Healthcare) and the resulting plasmids were used to transform $E$.

110 coli strain Rosetta2 (DE3) (Novagen). The protein construct contained a thrombin-cleavable

111 GST-tag before the DGK $\alpha-C D$ sequence. Cells were cultured in LB media at $37^{\circ} \mathrm{C}$ until $\mathrm{OD}_{600}$

112 reached 0.6-0.8. Expression of the recombinant protein was then induced by adding $0.5 \mathrm{mM}$

113 isopropyl $\beta$-D-thiogalactopyranoside (IPTG), and the bacterial culture was continued at $16^{\circ} \mathrm{C}$ for

114 overnight. Bacteria harvested by centrifugation were suspended in a lysis buffer (50 mM sodium

115 phosphate, $\mathrm{pH} 8.0$, containing $500 \mathrm{mM} \mathrm{NaCl}, 1 \mathrm{mM}$ phenylmethylsulfonyl fluoride, $1 \mathrm{mM}$

116 dithiothreitol) and lysed by sonication on ice. Protease inhibitors (20 $\mu \mathrm{g} / \mathrm{mL}$ aprotinin, $20 \mu \mathrm{g} / \mathrm{mL}$

117 leupeptin, $20 \mu \mathrm{g} / \mathrm{mL}$ pepstatin, $1 \mathrm{mM}$ soybean trypsin inhibitor) were added immediately before

118 sonication. To evaluate expression and solubility of the expressed proteins, soluble and insoluble

119 fractions were separated by centrifugation at $15,000 \mathrm{x}$ g for $10 \mathrm{~min}$ and subjected to SDS-PAGE

$120(10 \%)$ followed by Coomassie Brilliant Blue (CBB) staining and immunoblot analysis using

121 anti-GST monoclonal antibody (B-14, Santa Cruz Biotechnology). The immunoreactive bands

122 were visualized using peroxidase-conjugated anti-mouse IgG antibodies (Jackson

123 ImmunoResearch Laboratories) and the ECL Western blotting detection system (GE Healthcare).

124 For Sumo-tag, the DNA sequences of DGK $\alpha-C D$ (S332-G722, D344-G722, D369-

125 G722, S332-S735, D344-S735, D369-S735) were cloned via NdeI/SalI sites into pSUMO

126 vector. In addition, three constructs with additional two glutamic acids at the C-terminus (S332-

127 S735EE, D344-S735EE, D369-S735EE) were also cloned into the pSUMO vector. The

128 resulting recombinant protein contains an N-terminal His-tagged Sumo domain, followed by a

129 Sumo-specific protease (Ulp1) cleavage site before the DGK $\alpha$-CD sequence. His ${ }_{x 6}$-Sumo-

130 DGKa-CD was expressed in E. coli Rosetta2 (DE3) cells by induction with $0.1 \mathrm{mM}$ IPTG at 
$13116^{\circ} \mathrm{C}$ for overnight. After a small-scale expression and solubility test using anti-His ${ }_{\mathrm{x} 6}$

132 monoclonal antibody (9C11, Wako), large scale expression of the construct D344-S735EE was

133 conducted. After cell-lysis and centrifugation, Ni-affinity chromatography was applied to purify

134 His $_{\mathrm{x} 6}$-Sumo-DGKa-CD (D344-S735EE). The column was washed with $50 \mathrm{mM}$ Tris-HCl, $\mathrm{pH}$

$1358.0,500 \mathrm{mM} \mathrm{NaCl}, 10 \mathrm{mM}$ and $50 \mathrm{mM}$ imidazole, and the bound proteins were eluted with 300

$136 \mathrm{mM}$ imidazole. An elution fraction containing $\mathrm{His}_{\mathrm{x} 6}$-Sumo-DGK $\alpha$-CD was concentrated using a

137 centrifugal filter (Amicon Ultra-15, Millipore), and applied to a Superdex 75 16/60 column for

138 size exclusion chromatography purification.

139 MBP-fused DGK $\alpha-C D$ constructs were prepared by cloning the sequences of DGK $\alpha$-CD

140 (S332-G722, D344-G722, D369-G722, S332-S735, D344-S735, D369-S735, S332-S735EE,

141 D344-S735EE, D369-S735EE) into a pMAL-c2X vector (New England Biolabs) via

142 BamHI/SalI sites. E. coli strain Rosetta2 (DE3) transformed with the plasmids. Protein

143 expression was induced with $0.1 \mathrm{mM}$ IPTG and bacterial cells were then incubated at $16^{\circ} \mathrm{C}$ for

144 overnight. After cell-lysis and centrifugation, the expression and solubility test was conducted by

145 subjecting soluble and insoluble fractions on SDS-PAGE (10\%) followed by CBB staining and

146 immunoblot analysis using anti-MBP antibody (Sc-13564, Santa Cruz Biotechnology). The

147 construct MBP-DGK $\alpha-C D$ (D369-S735) was expressed in 2 L of LB medium and the MBP-

148 fused protein was purified by affinity chromatography on amylose resin (New England Biolabs).

149 The affinity column was washed with a buffer, $20 \mathrm{mM}$ Tris-HCl, pH 7.4, $200 \mathrm{mM} \mathrm{NaCl}, 1 \mathrm{mM}$

150 phenylmethylsulfonyl fluoride, $1 \mathrm{mM}$ EDTA, and the bound proteins were eluted with a buffer

151 containing $10 \mathrm{mM}$ maltose. Fractions were subjected to SDS-PAGE (10\%) and analyzed by CBB

152 staining and immunoblotting using anti-MBP antibody and anti-DGK $\alpha$ antibody (Yamada,

153 Sakane \& Kanoh, 1989).

154 Expression of DGKa in insect cells using baculovirus expression vector system

155 The construct of DGK $\alpha-C D$ (D364-S735) or full-length DGK $\alpha$ with N-terminal His ${ }_{x 6}$ tag was

156 PCR-amplified and cloned into the pOET3 vector (Oxford Expression Technologies) via

157 SalI/NotI sites. The resulting DNA sequences were verified to be correct by DNA sequencing.

158 The flashBAC system (Oxford Expression Technologies) was used to generate a recombinant

159 baculovirus and the virus stock was amplified by several rounds of infection of Sf9 cells cultured

160 in Sf-900 II serum free medium (Invitrogen) at a low multiplicity of infection (MOI). Plaque 
161 assays were performed to determine titers of the amplified virus stocks. Both DGK $\alpha-C D$ and

162 full-length DGK $\alpha$ were expressed in Sf9 cells by infecting the cells (at $2 \times 10^{6}$ cells $/ \mathrm{ml}$ ) with the

163 baculovirus stock at MOI of 2. Cells were cultured at $28^{\circ} \mathrm{C}$ with shaking for 24 hours and

164 pelleted by centrifugation at $1,500 \mathrm{x} \mathrm{g}, 4^{\circ} \mathrm{C}$ for $20 \mathrm{~min}$ and washed with sterile phosphate

165 buffered saline before storage at $-80^{\circ} \mathrm{C}$.

\section{Purification of DGKa expressed in insect cells}

167 The cell pellets were thawed and suspended in a lysis buffer containing $50 \mathrm{mM}$ Tris- $\mathrm{HCl}, \mathrm{pH}$ 8.0, 0.5 M NaCl, $20 \mathrm{mM}$ imidazole, 20\% glycerol, $5 \mathrm{mM} \mathrm{CaCl}_{2}, 5 \mathrm{mM} \mathrm{MgCl}$, $5 \mathrm{mM} \beta-$ mercaptoethanol, 1\% Nonidet P-40 (NP-40), $5 \mathrm{mM}$ ADP, $5 \mathrm{U} / \mathrm{mL}$ benzonase (EMD Millipore) and a EDTA-free protease inhibitor cocktail tablet (Roche). The cell suspension was lysed by sonication on ice followed by centrifugation at $25,000 \mathrm{x} \mathrm{g}, 4^{\circ} \mathrm{C}$ for 1 hour. The supernatant was incubated with $2 \mathrm{~mL}$ of Ni-NTA agarose (Qiagen) for 2 hours at $4^{\circ} \mathrm{C}$, and then the mixture was packed into a column by gravity. The column was washed with wash buffer 1 (50 mM Tris-HCl, $\mathrm{pH}$ 8.0, 0.5 M NaCl, $20 \mathrm{mM}$ imidazole, $20 \%$ glycerol, $5 \mathrm{mM} \mathrm{CaCl}_{2}, 5 \mathrm{mM} \mathrm{MgCl}_{2}, 5 \mathrm{mM} \beta-$ mercaptoethanol, 1\% NP-40) and wash buffer 2 (50 mM Tris-HCl, pH 8.0, 0.5 M NaCl, $20 \mathrm{mM}$ imidazole, $20 \%$ glycerol, $5 \mathrm{mM} \mathrm{CaCl}_{2}, 5 \mathrm{mM} \mathrm{MgCl}_{2}, 5 \mathrm{mM} \beta$-mercaptoethanol and 10\% ethanol). Subsequently, the bound proteins were eluted with step-wise increase of imidazole concentration $(50,100$, and $200 \mathrm{mM})$ in a buffer consisting of $50 \mathrm{mM}$ Tris- $\mathrm{HCl}, \mathrm{pH} 8.0,0.5 \mathrm{M}$ $\mathrm{NaCl}, 20 \mathrm{mM}$ imidazole, $20 \%$ glycerol, $5 \mathrm{mM} \mathrm{CaCl}_{2}, 5 \mathrm{mM} \mathrm{MgCl}_{2}, 5 \mathrm{mM} \beta$-mercaptoethanol. Collected fractions were analyzed by SDS-PAGE with Coomassie blue staining and immunoblot analysis using anti-DGK $\alpha$ antibody (Yamada, Sakane \& Kanoh, 1989).

Fractions containing full-length DGK $\alpha$ were further purified using size-exclusion

183 chromatography on a Superdex 200 column 16/60 equilibrated with 20 mM Tris-HCl, pH 7.4

184 with $200 \mathrm{mM} \mathrm{NaCl}, 3 \mathrm{mM} \mathrm{CaCl}_{2}, 3 \mathrm{mM} \mathrm{MgCl}_{2}, 0.5 \mathrm{mM}$ dithiothreitol, and 5\% glycerol.

185 Resulting fractions were analyzed by SDS-PAGE followed by Coomassie blue staining. Protein quantification was done by Bradford assay or using the extinction coefficient, $\mathrm{E}_{0.1 \%}=1.14$. Gel filtration standards (Bio-Rad) containing thyroglobulin $(670 \mathrm{kDa}), \gamma$-globulin $(158 \mathrm{kDa})$, ovalbumin (44 kDa), myoglobin $(17 \mathrm{kDa})$, and vitamin B12 (1.3 kDa) were used to determine the molecular mass of proteins. 


\section{In vitro DGKa activity assay}

191 Activity of full-length DGK $\alpha$ was determined using the octyl- $\beta$-D-glucoside mixed micelle assay

192 combined with the ADP-Glo ${ }^{\mathrm{TM}}$ kinase assay kit (Promega), as previously described (Sato et al.,

193 2013; Liu et al., 2016). Briefly, the substrate micelle mixture containing $50 \mathrm{mM} n$-octyl- $\beta$-D-

194 glucoside (Dojindo), 10 mM (27 mol\%) phosphatidylserine (PS; Sigma-Aldrich), 2 mM (5.4

195 mol\%) 1,2-dioleolyl-sn-glycerol (DG; Sigma-Aldrich), 0.2 mM ATP in a final buffer consisting

196 of $50 \mathrm{mM}$ MOPS, pH 7.4, $100 \mathrm{mM} \mathrm{NaCl}, 20 \mathrm{mM} \mathrm{NaF}, 10 \mathrm{mM} \mathrm{MgCl} 2,1 \mu \mathrm{M} \mathrm{CaCl}_{2}$ was mixed

197 with $5 \mu \mathrm{L}$ of purified DGK $\alpha$ to initiate enzymatic reaction. The reaction mixtures were incubated

198 at $30^{\circ} \mathrm{C}$ for $30 \mathrm{~min}$. Subsequently, $25 \mu \mathrm{L}$ of ADP-Glo reagent was added and incubated at room

199 temperature for $40 \mathrm{~min}$ to terminate the enzyme reaction and deplete the remaining ATP. Kinase

200 Detection Reagent $(50 \mu \mathrm{L})$ was then added to convert the ADP produced from the kinase

201 reaction into ATP for a luciferase/luciferin reaction. The reaction was performed at room

202 temperature for $40 \mathrm{~min}$ and the luminescence from the luciferase/luciferin reaction was measured

203 with a GloMax microplate reader (GloMax, Promega). A standard curve for ADP was generated

204 by fitting a various concentration of ADP ranging from $25 \mu \mathrm{M}$ to $200 \mu \mathrm{M}$ and the corresponding

205 luminescence signals (RLU) by linear regression, and was used to convert the luminescence

206 intensities from DGK $\alpha$ reaction into ADP concentrations. To determine kinetic constants, the

207 activity assay was performed under a series of concentrations of ATP (20 $\mu \mathrm{M}$ to $1 \mathrm{mM})$ and DG

208 (0 to $5.4 \mathrm{~mol} \%$ ), respectively. DGK $\alpha$ purified by size exclusion chromatography was added to

$209100 \mathrm{ng}$ for each reaction and the assays were done in triplicate for each ATP or DG

210 concentrations. The $K_{m}$ value was obtained by fitting the kinase activity of DGK $\alpha$ with the

211 Michaelis-Menten equation using Prism 7 (GraphPad). To test the calcium dependency of DGK $\alpha$

212 activity, the enzyme activity was measured under the conditions containing either EGTA (3 mM)

213 or $\mathrm{CaCl}_{2}(0.6 \mathrm{mM})$.

\section{Inhibitor activity assay}

215 Inhibitory activity of a previously identified inhibitor, CU-3 (Liu et al., 2016), against DGK $\alpha$

216 was measured with the octyl- $\beta$-D-glucoside mixed micelle assay followed by the ADP-Glo

217 assay. A concentration series of CU-3 $(0.02$ to $10 \mu \mathrm{M})$ was incubated with the purified DGK $\alpha$ for

$21830 \mathrm{~min}$ at room temperature before adding to a reaction mixture for the assay. Half maximal 
219 inhibitory concentration (IC50) was determined by fitting the CU-3 dependent decrease of

220 DGK $\alpha$ activity with the variable slope model in Graphpad Prism 7 software.

\section{Circular dichroism spectroscopy}

222 Circular dichroism (CD) spectrum were recorded at ambient conditions between 190 and $250 \mathrm{~nm}$ 223 on a Jasco J-805 spectrometer (Jasco Corporation) using a cell with path length of $0.2 \mathrm{~mm}, 20$ $\mathrm{nm} / \mathrm{min}$ scan speed and a bandwidth of $1 \mathrm{~nm}$. DGK $\alpha$ was prepared at $0.32 \mathrm{mg} / \mathrm{mL}(3.75 \mu \mathrm{M})$ in

225

226

227

228

229

230

231

232

233

234

235

236

237

238

239

240

241

242

243

244

245

246

247

$20 \mathrm{mM}$ Tris- $\mathrm{HCl}$ buffer, $\mathrm{pH} 7.5$, Ten spectra were averaged and a spectrum obtained for the buffer was subtracted. Spectral data were analyzed using the program Contin-LL (Provencher \& Glöckner, 1981) suited in the DICHROWEB platform (Whitmore \& Wallace, 2004).

\section{Results}

A full-length form of DGKa was expressed in baculovirus-infected insect cells and purified as a monomer

We have previously reported that DGK $\alpha-C D$ possess enzymatic activity comparable to that of the full-length enzyme when expressed in COS-7 cells (Sakane et al., 1996), indicating that its substrate (ATP and DG) binding sites locate in the catalytic domain and DGK $\alpha-\mathrm{CD}$ is an essential target for inhibitor development. Full-length DGK $\alpha$ also contains cysteine-rich $\mathrm{C} 1$ domains (Fig. 1A), which might be detrimental for correct folding in heterologous expression hosts. Therefore, we have first attempted to express DGK $\alpha-C D$ in E.coli by revamping the previous approach by Petro et al. (Petro \& Raben, 2013). In addition to N-terminal GST and MBP-tags, which were previously utilized (Petro \& Raben, 2013), we have used Sumo domain fusion-tag for the enhancement of expression and solubility (Butt et al., 2005; Marblestone et al.). To further increase the chance for expression of soluble proteins, we have also applied a multiple-construct approach (Gräslund et al., 2008) to prepare DGK $\alpha$-CD constructs which have different N- and C-terminal boundaries (S332-G722, D344-G722, D369-G722, S332-S735, D344-S735, D369-S735). Each of those constructs was fused with the GST, MBP, and Sumotags. Despite our efforts, those constructs resulted in either insoluble inclusion body formation (with GST-tag), or insufficient translation and proteolytic degradation (with MBP-tag), or soluble microscopic aggregation (with Sumo-tag) (Fig. S1). 
To circumvent the difficulty associated with bacterial expression system, we have used baculovirus-infected Sf9 cells to produce DGK $\alpha-C D$. The construct of DGK $\alpha-C D$ (D364-S735) with $\mathrm{N}$-terminal $\mathrm{His}_{\mathrm{x} 6}$ tag was cloned into pOET3 transfer vector harboring the late AcMNPV p6.9 promoter, which provides earlier expression compared to the polyhedrin promotor. The recombinant DGK $\alpha-C D$ was expressed in cultured insect cells using the flashBAC baculovirus vector expression system, and subsequently purified from cell-lysates using Ni-affinity chromatography (Fig. S2A). Following size-exclusion chromatography on a Superdex 200, however, demonstrated that DGK $\alpha-C D$ formed soluble aggregates eluting in the void volume of the column (Fig. S2B).

In our early studies, a native form of full-length DGK $\alpha$ has been purified from porcine

258

259

260

261

262

263

264

265

266

267

268

269

270

271

\section{2}

273

274

275

276

277 thymus and this full-length form was found to be catalytically competent (Sakane, Yamada \& Kanoh, 1989; Sakane et al., 1991). We therefore set to produce full-length DGKa (aa 1-735) using the same baculovirus expression system used for DGK $\alpha-C D$. As expected, the vast majority of DGK $\alpha$ remained in soluble form after cell lysis, as shown by immunoblot analysis (Fig. 1B). Ni-affinity chromatography was conducted to purify DGK $\alpha$ from the cell lysis supernatant, and relatively pure DGK $\alpha$ was eluted in fractions containing $50 \mathrm{mM}$ and $100 \mathrm{mM}$ imidazole (Fig. 1C). To further purify DGK $\alpha$, we next performed size-exclusion chromatography on a Superdex 200 column. Because DGK $\alpha$ bears calcium-binding EF-hand motifs and a magnesium ion was predicted to bind to the catalytic domain (Abe et al., 2003), we added $3 \mathrm{mM}$ $\mathrm{CaCl}_{2}$ and $3 \mathrm{mM} \mathrm{MgCl}$ in the equilibration buffer. DGK $\alpha$ eluted as a single peak at $73.5 \mathrm{~mL}$ retention volume (Fig. 1D), which corresponds to the molecular mass of $77 \mathrm{kDa}$, based on a calibration curve obtained with molecular mass standard proteins. This result indicates that DGK $\alpha$ exists as a monomer in solution. DGK $\alpha$ was purified to near homogeneity (Fig. 1E) and the yield was approximately $1.3 \mathrm{mg}$ per $1 \mathrm{~L}$ of Sf9 cell culture.

\section{Kinase activity assay and inhibitory assay for the purified DGKa}

To test whether the purified DGK $\alpha$ is catalytically active, we conducted the octyl- $\beta$-D-glucoside mixed micelle assay combined with a luminescence-based assay that measures ADP produced in a kinase reaction (Sato et al., 2013; Liu et al., 2016). DGK $\alpha$ purified from the size-exclusion chromatography was found to exhibit kinase activity with peak fractions having the maximum activity (Fig. 2A). We have previously demonstrated that DGK $\alpha$ activity, which has been 
278 purified from porcine thymus or expressed in COS-7 cells, is enhanced by $\mathrm{Ca}^{2+}$ binding to its 279 two N-terminal EF-hand motifs (Sakane et al., 1990; 1991; Yamada et al., 1997). As predicted, 280 the purified DGK $\alpha$ exhibited significantly reduced activity when the bound calcium ions were 281 chelated with 5 mM EGTA (Fig. 2B). Furthermore, no significant changes of the activity were 282 observed after storage of the purified DGK $\alpha$ at $4^{\circ} \mathrm{C}$ for at least 3 months.

283 We also determined the kinetic parameters of DGK $\alpha$ for ATP and DG to assess the 284 catalytic properties of the purified DGK $\alpha$. ATP-dependent increase of the kinase activity was 285 observed (Fig. 3A) and the $K_{m}$ value was determined to be $0.24 \pm 0.03 \mathrm{mM}$ (Table 1),

286 comparable with those obtained with DGKa from porcine thymus $(0.1 \mathrm{mM})$ (Sakane et al., 1991) 287 or DGK $\alpha$ expressed in COS-7 cells (0.1-0.25 mM) (Sato et al., 2013; Liu et al., 2016). The 288 activity was also increased in a DG-concentration dependent manner (Fig. 3B) and the $K_{m}$ value 289 of $1.1 \pm 0.21 \mathrm{~mol} \%$ (Table 1) was consistent with those from our previous studies ( $3.3 \mathrm{~mol} \%$ 290 with DGK $\alpha$ purified from porcine thymus (Sakane et al., 1991), 1.9-3.4 mol\% with DGK $\alpha$ 291 expressed in COS-7 cells (Sato et al., 2013; Liu et al., 2016)). For both cases, compared to our 292 previous study using crude lysates of mammalian cells (Sato et al., 2013; Liu et al., 2016), the 293 relative activity increased nearly 50-fold when the purified DGKa was used. Furthermore, the 294 kinase activities of our purified DGK $\alpha(1-2 \mathrm{nmol} / \mathrm{min} / \mu \mathrm{g})$ is comparable to those obtained with 295 DGK $\alpha$ from porcine thymus $(2.4 \mathrm{nmol} / \mathrm{min} / \mu \mathrm{g}$ ) (Sakane et al., 1991). These results demonstrate 296 that the purified DGKa is in a fully functional state and stable during purification and storage.

We next measured the inhibitory activity of CU-3, a previously identified DGK $\alpha$ 298 inhibitor (Liu et al., 2016). CU-3 is an ATP competitive inhibitor with an $\mathrm{IC}_{50}$ value of $0.6 \mu \mathrm{M}$.

299 Consistent with this, CU-3 inhibited the activity of DGK $\alpha$ in a concentration-dependent manner 300 with an $\mathrm{IC}_{50}$ value of $0.34 \pm 0.1 \mu \mathrm{M}$ (Fig. 4).

\section{Structural characterization of the purified DGKa}

302 We also found that DGKa solution could be concentrated using a centrifugal filter without any

303 significant loss of the protein. Concentrated DGK $\alpha$ remained as a monomer as demonstrated by a 304 size-exclusion chromatography (Fig. S3). Using the concentrated DGK $\alpha(0.32 \mathrm{mg} / \mathrm{mL})$, we 305 characterized the secondary structure using CD spectroscopy. The CD spectrum of DGK $\alpha$ and 306 following analysis indicates that DGK $\alpha$ is well-folded and contains certain amounts of $\alpha$-helical 307 (18.9\%) and $\beta$-strand (27.4\%) structures (Fig. 5), further demonstrating that the expression of a 
308 full-length DGK $\alpha$, not a solo catalytic domain, in the baculovirus-infected insect cells is suitable

309 for producing a natively-folded and active form of DGK $\alpha$.

310

\section{Discussion}

312 DGKs are a family of multi-domain lipid kinase that regulate a variety of cellular process

313 (Sakane et al., 2007; Merida, Ávila-Flores \& Merino, 2008; Shulga, Topham \& Epand, 2011),

314 and DGK $\alpha$ has recently emerged as a novel therapeutic target for cancer immunotherapy

315 (Dominguez et al., 2013; Purow, 2015; Sakane, Mizuno \& Komenoi, 2016; Liu et al., 2016;

316 Noessner, 2017). However, no structural information of DGKs, especially their catalytic domain,

317 is available. This is largely because the procedure for large scale production of recombinant

318 DGKs in their soluble and homogeneous form, a prerequisite for protein crystallization, is not

319 well-established. Here we have used the baculovirus-insect cell expression system to produce a

320 full-length form (DGK $\alpha$ ), and investigated the enzymatic and structural properties in vitro.

321 Petro and Raben have made significant efforts to express and purify a pig DGK $\alpha$ and

322 DGK $\alpha$-CD using bacterial expression system with several fusion tags (GST, TRX, and MBP), a

323 set of bacterial chaperons, or in-vitro refolding (Petro \& Raben, 2013). Despite their pursuit,

324 expressed DGK $\alpha$ constructs either formed inclusion bodies or soluble microscopic aggregates.

325 We have also used E.coli cells to produce DGKa-CD with several N-terminal fusion tags (GST,

326 Sumo, and MBP) and with different N- and C-terminal boundaries. While both MBP- and Sumo-

327 fused DGK $\alpha-C D$ remained in a soluble fraction after cell-lysis and Ni-affinity chromatography

328 (Fig. S1A and S1B), those DGK $\alpha$-CD with fusion-tags eluted in the void volume of Superdex

329200 column (Fig. S1C). When expressed with MBP, an elution fraction from the Ni-affinity

330 chromatography also contained additional smaller bands along with MBP-fused DGKa-CD (Fig.

331 S1A), which could be due to insufficient translational ability of E.coli for producing eukaryotic

332 proteins, as previously suggested (Petro \& Raben, 2013). Because baculovirus-insect cell

333 expression system has both the capacity to produce recombinant proteins at a large scale and the

334 capability to provide eukaryotic protein expression machineries, we next utilized this system to

335 produce DGK $\alpha-C D$. The protein expressed in Sf9 cells was soluble, however, contrary to our

336 expectation, the protein formed soluble aggregates, which eluted in the void volume (Fig. S2).

337 These results indicate that the only catalytic domain has a tendency to self-aggregate upon 
338 isolation, possibly due to its intrinsic characteristics that recognize DG embedded in plasma

339 membrane, and suggest that the only catalytic domain is not suitable for structural studies even if

340 it is expressed using a eukaryotic expression system.

341 In contrast to the catalytic domain, full-length DGK $\alpha$ elutes in a relatively sharp peak of

342 size-exclusion chromatography and remains as a monomer when it is assumed to have a globular

343 shape (Fig. 1C and Fig. S3). Such production of a full-length DGKa in a soluble and monomeric

344 form using the baculovirus insect cell expression system holds promise for the preparation of

345 DGKa sample suitable for protein crystallization screening. DGK $\alpha$ consists of the $\mathrm{N}$-terminal

346 regulatory domains including EF-hand motifs and $\mathrm{C} 1$ domains, and the $\mathrm{C}$-terminal catalytic

347 domain. This suggests that DGK $\alpha$ adopts a compact globular structure rather than an elongated

348 one. YegS (a putative bacterial lipid kinase) (Bakali H, Nordlund \& Hallberg, 2006), a bacterial

349 DgkB (Miller et al., 2008), and a human sphingosine kinase (SphK1) (Wang et al., 2013) have

350 been successfully purified and their crystal structures have been reported (Bakali $\mathrm{H}$ et al., 2007;

351 Miller et al., 2008; Wang et al., 2013). Although all of those lipid kinases are homologous to

352 mammalian DGKs and belong to a protein family PF00781 (DAGK_cat), they do not possess N-

353 terminal regulatory domains. This might explain why the N-terminal domain of DGKa is

354 required to obtain the protein as a soluble monomer. Interestingly, previous studies by us and

355 others have suggested the presence of intramolecular interactions between the $\mathrm{N}$-terminal

356 regulatory domains and the catalytic domain (Merino et al., 2007; Takahashi et al., 2012). It is

357 reasonable to surmise that a potential aggregation-prone surface of the catalytic domain of

358 DGK $\alpha$ is intra-molecularly masked by the N-terminal regulatory domains including recoverin

359 homology, EF-hand motif, and $\mathrm{C} 1$ domains.

360 Enzymatic characterization of DGK $\alpha$ reveals that $K_{m}$ values to ATP $(0.24 \mathrm{mM})$ and DG

361 (1.1 mol\%) are very similar to those obtained using DGK $\alpha$ partially purified from porcine

362 thymus (0.1 mM for ATP and $3.3 \mathrm{~mol} \%$ for DG, respectively) (Sakane et al., 1991) or DGK $\alpha$

363 expressed in COS-7 cells (0.1-0.25 mM for ATP and 1.9-3.4 mol\% for DG, respectively) (Sato

364 et al., 2013; Liu et al., 2016), further demonstrating the effectiveness of baculovirus insect cell

365 expression system for producing DGK $\alpha$ not only in soluble and homogeneous form, but also in

366 its active one. 
369 DGK $\alpha-C D$ alone, using the baculovirus-insect cell expression is a very promising approach to 370 produce DGK $\alpha$ samples for future in vitro structural and functional studies. Firstly, DGK $\alpha$ has

371 been purified by Ni-affinity and size-exclusion chromatographies to near-homogeneity, and

372 purified DGK $\alpha$ remains in soluble and monomeric form, and can be concentrated without any

373 significant loss of the protein, which are prerequisites for protein crystallization. Purified DGK $\alpha$

374 sample, however, still contains slight amounts of contaminant proteins which might non-

375 specifically bind to DGK $\alpha$. Further modification and optimization of the protein construct and

376 purification conditions must be required. Secondly, the obtained yield of DGK $\alpha, 1.3 \mathrm{mg}$ per $1 \mathrm{~L}$

377 cell culture, is enough to initiate crystal screening. Thirdly, the purified DGK $\alpha$ is catalytically

378 competent. The measured kinase activity and the $K_{m}$ values to ATP and DG are comparable to

379 those obtained with native form of DGK $\alpha$ partially purified from porcine thymus and DGK $\alpha$

380 expressed in mammalian cells.

382 Conclusion

383 We demonstrate that the baculovirus-insect cell expression of the full-length form of DGK $\alpha$, not 384 DGK $\alpha-C D$ alone, represents a promising approach to produce protein sample suitable for

385 structural studies of DGK $\alpha$. We believe that this study will encourage future pursuits to

386 determine crystal structures of mammalian DGKs that has still remained enigmatic for almost 60

387 years since its identification (Hokin \& Hokin, 1959).

388

389 Acknowledgements

390 We thank Dr. Saurav Misra from Kansas State University for helpful suggestions regarding this

391 work. We thank Dr. Haobo Jiang from Oklahoma State University for providing pSUMO vector.

392 We thank Dr. Naoto Yonezawa (Chiba University) for giving Sf9 cells. We are grateful to Dr.

393 Takeshi Murata (Chiba University) for the use of their BioLogic chromatography system. 394 
421

422

423

424

425

426

427

428

429

430

431

432

433

434

435

436

437

438

439

\section{References}

Abe T, Lu X, Jiang Y, Boccone CE, Qian S, Vattem KM, Wek RC, Walsh JP 2003. Site-directed mutagenesis of the active site of diacylglycerol kinase alpha: calcium and phosphatidylserine stimulate enzyme activity via distinct mechanisms. Biochemical Journal 375:673-680. DOI: 10.1042/BJ20031052.

Almena M, Merida I 2011. Shaping up the membrane: diacylglycerol coordinates spatial orientation of signaling. Trends in Biochemical Sciences 36:593-603. DOI: 10.1016/j.tibs.2011.06.005.

Ávila-Flores A, Santos T, Rincón E, Merida I 2005. Modulation of the mammalian target of rapamycin pathway by diacylglycerol kinase-produced phosphatidic acid. Journal of Biological Chemistry 280:10091-10099. DOI: 10.1074/jbc.M412296200.

Bacchiocchi R, Baldanzi G, Carbonari D, Capomagi C, Colombo E, van Blitterswijk WJ, Graziani A, Fazioli F 2005. Activation of alpha-diacylglycerol kinase is critical for the mitogenic properties of anaplastic lymphoma kinase. Blood 106:2175-2182. DOI: 10.1182/blood-2005-01-0316.

Bakali H MA, Herman MD, Johnson KA, Kelly AA, Wieslander A, Hallberg BM, Nordlund P 2007. Crystal structure of YegS, a homologue to the mammalian diacylglycerol kinases, reveals a novel regulatory metal binding site. Journal of Biological Chemistry 282:1964419652. DOI: 10.1074/jbc.M604852200.

Bakali H MA, Nordlund P, Hallberg BM 2006. Expression, purification, crystallization and preliminary diffraction studies of the mammalian DAG kinase homologue YegS from Escherichia coli. Acta Crystallographica Section F Structural Biology and Crystallization Communications 62:295-297. DOI: 10.1107/S1744309106004799.

Butt TR, Edavettal SC, Hall JP, Mattern MR 2005. SUMO fusion technology for difficult-toexpress proteins. Protein Expression and Purification 43:1-9. DOI: 10.1016/j.pep.2005.03.016.

Dominguez CL, Floyd DH, Xiao A, Mullins GR, Kefas BA, Xin W, Yacur MN, Abounader R, Lee JK, Wilson GM, Harris TE, Purow BW 2013. Diacylglycerol kinase $\alpha$ is a critical signaling node and novel therapeutic target in glioblastoma and other cancers. Cancer Discovery 3:782-797. DOI: 10.1158/2159-8290.CD-12-0215.

Ebinu JO, Bottorff DA, Chan EYW, Stang SL, Dunn RJ, Stone JC 1998. RasGRP, a Ras Guanyl Nucleotide- Releasing Protein with Calcium- and Diacylglycerol-Binding Motifs. Science 280:1082-1086. DOI: 10.1126/science.280.5366.1082.

English D 1996. Phosphatidic acid: A lipid messenger involved in intracellular and extracellular signalling. Cellular Signalling 8:341-347. DOI: 10.1016/0898-6568(95)00076-3.

Gräslund S, Nordlund P, Weigelt J, Bray J, Gileadi O, Knapp S, Oppermann U, Arrowsmith C, Hui R, Ming J, dhe-Paganon S, Park H-W, Savchenko A, Yee A, Edwards A, Vincentelli R, Cambillau C, Kim R, Kim S-H, Rao Z, Shi Y, Terwilliger TC, Kim C-Y, Hung L-W, Waldo GS, Peleg Y, Albeck S, Unger T, Dym O, Prilusky J, Sussman JL, Stevens RC, Lesley SA, Wilson IA, Joachimiak A, Collart F, Dementieva I, Donnelly MI, Eschenfeldt WH, Kim Y, Stols L, Wu R, Zhou M, Burley SK, Emtage JS, Sauder JM, Thompson D, Bain K, Luz J, Gheyi T, Zhang F, Atwell S, Almo SC, Bonanno JB, Fiser A, Swaminathan S, Studier FW, Chance MR, Sali A, Acton TB, Xiao R, Zhao L, Ma L-C, Hunt JF, Tong L, Cunningham K, Inouye M, Anderson S, Janjua H, Shastry R, Ho CK, Wang D, Wang H, Jiang M, Montelione GT, Stuart DI, Owens RJ, Daenke S, Schütz A, Heinemann U, Yokoyama S, 
440

441

442

443

444

445

446

447

448

449

450

451

452

453

454

455

456

457

458

459

460

461

462

463

464

465

466

467

468

469

470

471

472

473

474

475

476

477

478

479

480

481

482

483

484

485

Büssow K, Gunsalus KC 2008. Protein production and purification. Nature Methods 5:135146. DOI: 10.1038/nmeth.f.202.

Griner EM, Kazanietz MG 2007. Protein kinase C and other diacylglycerol effectors in cancer. Nature reviews. Cancer 7:281-294. DOI: 10.1038/nrc2110.

Hokin LE, Hokin MR 1959. Diglyceride phosphokinase: An enzyme which catalyzes the synthesis of phosphatidic acid. Biochimica et Biophysica Acta 31:285-287. DOI: 10.1016/0006-3002(59)90481-0.

Jones DR 2002. Expression of a catalytically inactive form of diacylglycerol kinase a induces sustained signaling through RasGRP. The FASEB Journal. DOI: 10.1096/fj.01-0762fje.

Liu K, Kunii N, Sakuma M, Yamaki A, Mizuno S, Sato M, Sakai H, Kado S, Kumagai K, Kojima H, Okabe T, Nagano T, Shirai Y, Sakane F 2016. A novel diacylglycerol kinase $\alpha-$ selective inhibitor, CU-3, induces cancer cell apoptosis and enhances immune response. Journal of Lipid Research 57:368-379. DOI: 10.1194/j1r.M062794.

Marblestone JG, Edavettal SC, Lim Y, Protein PL 2006. Comparison of SUMO fusion technology with traditional gene fusion systems: enhanced expression and solubility with SUMO. Protein Science 15:182-189. DOI: 10.1110/ps.051812706.

Merida I, Ávila-Flores A, Merino E 2008. Diacylglycerol kinases: at the hub of cell signalling. Biochemical Journal 409:1-18. DOI: 10.1042/BJ20071040.

Merida I, Torres-Ayuso P, Ávila-Flores A, Arranz-Nicolás J, Andrada E, Tello-Lafoz M, Liébana R, Arcos R 2017. Diacylglycerol kinases in cancer. Advances in Biological Regulation 63:22-31. DOI: 10.1016/j.jbior.2016.09.005.

Merino E, Sanjuán MA, Moraga I, Ciprés A, Merida I 2007. Role of the diacylglycerol kinase alpha-conserved domains in membrane targeting in intact T cells. Journal of Biological Chemistry 282:35396-35404. DOI: 10.1074/jbc.M702085200.

Miller DJ, Jerga A, Rock CO, White SW 2008. Analysis of the Staphylococcus aureus DgkB Structure Reveals a Common Catalytic Mechanism for the Soluble Diacylglycerol Kinases. Structure 16:1036-1046. DOI: 10.1016/j.str.2008.03.019.

Moritz A, De Graan PN, Gispen WH, Wirtz KW 1992. Phosphatidic acid is a specific activator of phosphatidylinositol-4-phosphate kinase. Journal of Biological Chemistry 267:72077210 .

Newton AC 1997. Regulation of protein kinase C. Current Opinion in Cell Biology 9:161-167. DOI: $10.1016 / \mathrm{S} 0955-0674(97) 80058-0$.

Noessner E 2017. Diacylglycerol kinase-alpha: a checkpoint in cancer-mediated immunoinhibition and target for immunotherapy. Frontiers in Cell and Developmental Biology. DOI: 10.3389/fcell.2017.00016.

Olenchock BA, Guo R, Carpenter JH, Jordan M, Topham MK, Koretzky GA, Zhong X-P 2006. Disruption of diacylglycerol metabolism impairs the induction of T cell anergy. Nature Immunology 7:1174-1181. DOI: 10.1038/ni1400.

Parekh DB, Ziegler W, Parker PJ 2000. Multiple pathways control protein kinase C phosphorylation. The EMBO journal 19:496-503. DOI: 10.1093/emboj/19.4.496.

Petro EJ, Raben DM 2013. Bacterial expression strategies for several Sus scrofa diacylglycerol kinase alpha constructs: solubility challenges. Scientific Reports 3:352-14. DOI: 10.1038/srep01609.

Provencher SW, Glöckner J 1981. Estimation of globular protein secondary structure from circular dichroism. Biochemistry 20:33-37. DOI: 10.1021/bi00504a006.

Purow B 2015. Molecular Pathways: Targeting Diacylglycerol Kinase Alpha in Cancer. Clinical

PeerJ reviewing PDF | (2018:05:28290:1:0:NEW 18 Jul 2018) 
486

487

488

489

490

491

492

493

494

495

496

497

498

499

500

501

502

503

504

505

506

507

508

509

510

511

512

513

514

515

516

517

518

519

520

521

522

523

524

525

526

527

528

529

530

531

Cancer Research 21:5008-5012. DOI: 10.1158/1078-0432.CCR-15-0413.

Sakane F, Imai S-I, Kai M, Yasuda S, Kanoh H 2007. Diacylglycerol kinases: why so many of them? Biochimica et Biophysica Acta 1771:793-806. DOI: 10.1016/j.bbalip.2007.04.006.

Sakane F, Kai M, Wada I, Imai S-I, Kanoh H 1996. The C-terminal part of diacylglycerol kinase alpha lacking zinc fingers serves as a catalytic domain. Biochemical Journal 318:583-590.

Sakane F, Mizuno S, Komenoi S 2016. Diacylglycerol Kinases as Emerging Potential Drug Targets for a Variety of Diseases: An Update. Frontiers in Cell and Developmental Biology 4:82. DOI: 10.3389/fcell.2016.00082.

Sakane F, Yamada K, Kanoh H 1989. Different effects of sphingosine, R59022 and anionic amphiphiles on two diacylglycerol kinase isozymes purified from porcine thymus cytosol. FEBS Letters 255:409-413.

Sakane F, Yamada K, Imai S-I, Kanoh H 1991. Porcine 80-kDa diacylglycerol kinase is a calcium-binding and calcium/phospholipid-dependent enzyme and undergoes calciumdependent translocation. Journal of Biological Chemistry 266:7096-7100.

Sakane F, Yamada K, Kanoh H, Yokoyama C, Tanabe T 1990. Porcine diacylglycerol kinase sequence has zinc finger and E-F hand motifs. Nature 344:345-348. DOI: $10.1038 / 344345 \mathrm{a} 0$.

Sato M, Liu K, Sasaki S, Kunii N, Sakai H, Mizuno H, Saga H, Sakane F 2013. Evaluations of the Selectivities of the Diacylglycerol Kinase Inhibitors R59022 and R59949 Among Diacylglycerol Kinase Isozymes Using a New Non-Radioactive Assay Method. Pharmacology 92:99-107. DOI: 10.1159/000351849.

Shulga YV, Topham MK, Epand RM 2011. Regulation and Functions of Diacylglycerol Kinases. Chemical Reviews 111:6186-6208. DOI: 10.1021/cr1004106.

Stace CL, Ktistakis NT 2006. Phosphatidic acid- and phosphatidylserine-binding proteins. Biochimica et Biophysica Acta - Molecular and Cell Biology of Lipids 1761:913-926. DOI: 10.1016/j.bbalip.2006.03.006.

Takahashi M, Yamamoto T, Sakai H, Sakane F 2012. Calcium negatively regulates an intramolecular interaction between the N-terminal recoverin homology and EF-hand motif domains and the C-terminal C1 and catalytic domains of diacylglycerol kinase $\hat{\mathrm{I}} \pm$. Biochemical and Biophysical Research Communications 423:571-576. DOI:

10.1016/j.bbrc.2012.06.006.

Takeishi K, Taketomi A, Shirabe K, Toshima T, Motomura T, Ikegami T, Yoshizumi T, Sakane F, Maehara Y 2012. Diacylglycerol kinase alpha enhances hepatocellular carcinoma progression by activation of Ras-Raf-MEK-ERK pathway. Journal of Hepatology 57:77-83. DOI: 10.1016/j.jhep.2012.02.026.

Tognon CE, Kirk HE, Passmore LA, Whitehead IP, Der CJ, Kay RJ 1998. Regulation of RasGRP via a Phorbol Ester-Responsive C1 Domain. Molecular and Cellular Biology 18:6995-7008. DOI: 10.1128/MCB.18.12.6995.

Torres-Ayuso P, Daza-Martín M, Martín-Pérez J, Ávila-Flores A, Merida I 2014. Diacylglycerol kinase $\alpha$ promotes 3D cancer cell growth and limits drug sensitivity through functional interaction with Src. Oncotarget 5:9710-9726. DOI: 10.18632/oncotarget.2344.

Wang Z, Min X, Xiao S-H, Johnstone S, Romanow W, Meininger D, Xu H, Liu J, Dai J, An S, Thibault S, Walker N 2013. Molecular basis of sphingosine kinase 1 substrate recognition and catalysis. Structure 21:798-809. DOI: 10.1016/j.str.2013.02.025.

Whitmore L, Wallace BA 2004. DICHROWEB, an online server for protein secondary structure analyses from circular dichroism spectroscopic data. Nucleic Acids Research 32:W668- 
532

533

534

535

536

537

538

539

540

541

542

543

544

545

546

W673. DOI: 10.1093/nar/gkh371.

Yamada K, Sakane F, Kanoh H 1989. Immunoquantitation of $80 \mathrm{kDa}$ diacylglycerol kinase in pig and human lymphocytes and several other cells. FEBS Letters 244:402-406.

Yamada K, Sakane F, Matsushima N, Kanoh H 1997. EF-hand motifs of $\alpha, \beta$ and $\gamma$ isoforms of diacylglycerol kinase bind calcium with different affinities and conformational changes. Biochemical Journal 321:59-64.

Yanagisawa K, Yasuda S, Kai M, Imai S-I, Yamada K, Yamashita T, Jimbow K, Kanoh H, Sakane F 2007. Diacylglycerol kinase $\alpha$ suppresses tumor necrosis factor- $\alpha$-induced apoptosis of human melanoma cells through NF-kB activation. Biochimica et Biophysica Acta - Molecular and Cell Biology of Lipids 1771:462-474. DOI: 10.1016/j.bbalip.2006.12.008.

Zha Y, Marks R, Ho AW, Peterson AC, Janardhan S, Brown I, Praveen K, Stang S, Stone JC, Gajewski TF 2006. T cell anergy is reversed by active Ras and is regulated by diacylglycerol kinase-alpha. Nature Immunology 7:1166-1173. DOI: 10.1038/ni1394. 


\section{Table 1 (on next page)}

Enzyme kinetic parameters of DGK $\alpha$ with ATP and diaclyglycerol 
1 Table 1: Enzyme kinetic parameters of DGKa with ATP and diaclyglycerol

2

\begin{tabular}{lll} 
Substrate & $K_{m}$ & $V_{\max }$ \\
\hline ATP & $0.24 \pm 0.03 \mathrm{mM}$ & $2.66 \pm 0.15 \mathrm{nmol} / \mathrm{min} / \mu \mathrm{g}$ \\
Diacylglycerol & $1.06 \pm 0.21 \mathrm{~mol} \%$ & $1.00 \pm 0.06 \mathrm{nmol} / \mathrm{min} / \mu \mathrm{g}$
\end{tabular}




\section{Figure 1}

Expression of DGKa in baculovirus-infected insect cells and purification.

(A) Domain architecture of DGK $\alpha$. RVH, recoverin homology domain; EF, EF-hand motif; $\mathrm{Cl}$, cysteine-rich C1 domain. (B) Immunoblot analysis of the solubility of a full-length DGKa expressed in Sf9 cells. Cell lysates were separated into supernatant and insoluble pellets and subjected to SDS-PAGE (10\%) followed by immunoblot analysis using anti-DGKa antibody. (C) SDS-PAGE (10\%) analysis of fractions from $\mathrm{Ni}^{2+}$-affinity purification. Separated proteins were stained with Coomassie blue staining. (D) Elution profile of DGKa from size exclusion chromatography. Fractions numbers used for following SDS-PAGE analysis are labeled. The inset shows the calibration of gel-filtration column using protein standards of known molecular weight (thyroglobulin (670 kDa), y-globulin (158 kDa), ovalbumin (44 kDa), myoglobin $(17 \mathrm{kDa}))$. Partition coefficient $\left(K_{\mathrm{av}}\right)$ was calculated from the formula, $K_{\mathrm{av}}=$ $\left(V_{\mathrm{E}}-V_{0}\right) /\left(V_{\mathrm{T}}-V_{0}\right)$, where $V_{\mathrm{E}}$ is the retention volume of each sample, $V_{\mathrm{T}}$ is the total column volume $(120 \mathrm{~mL})$, and $V_{0}$ is the void volume of the column $(44 \mathrm{~mL})$, respectively. $K_{\mathrm{av}}$ was plotted against the molecular weight of proteins and linear regression analysis was conducted. (E) SDS-PAGE (10\%) analysis of DGKa purified using size-exclusion chromatography. 
A

$\mathrm{DGK} \alpha$

B

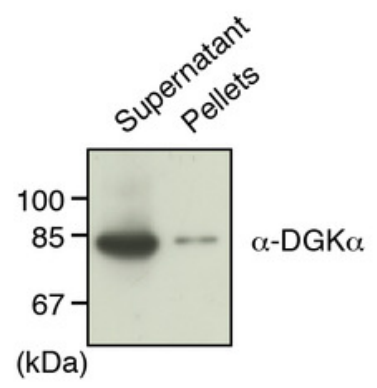

C
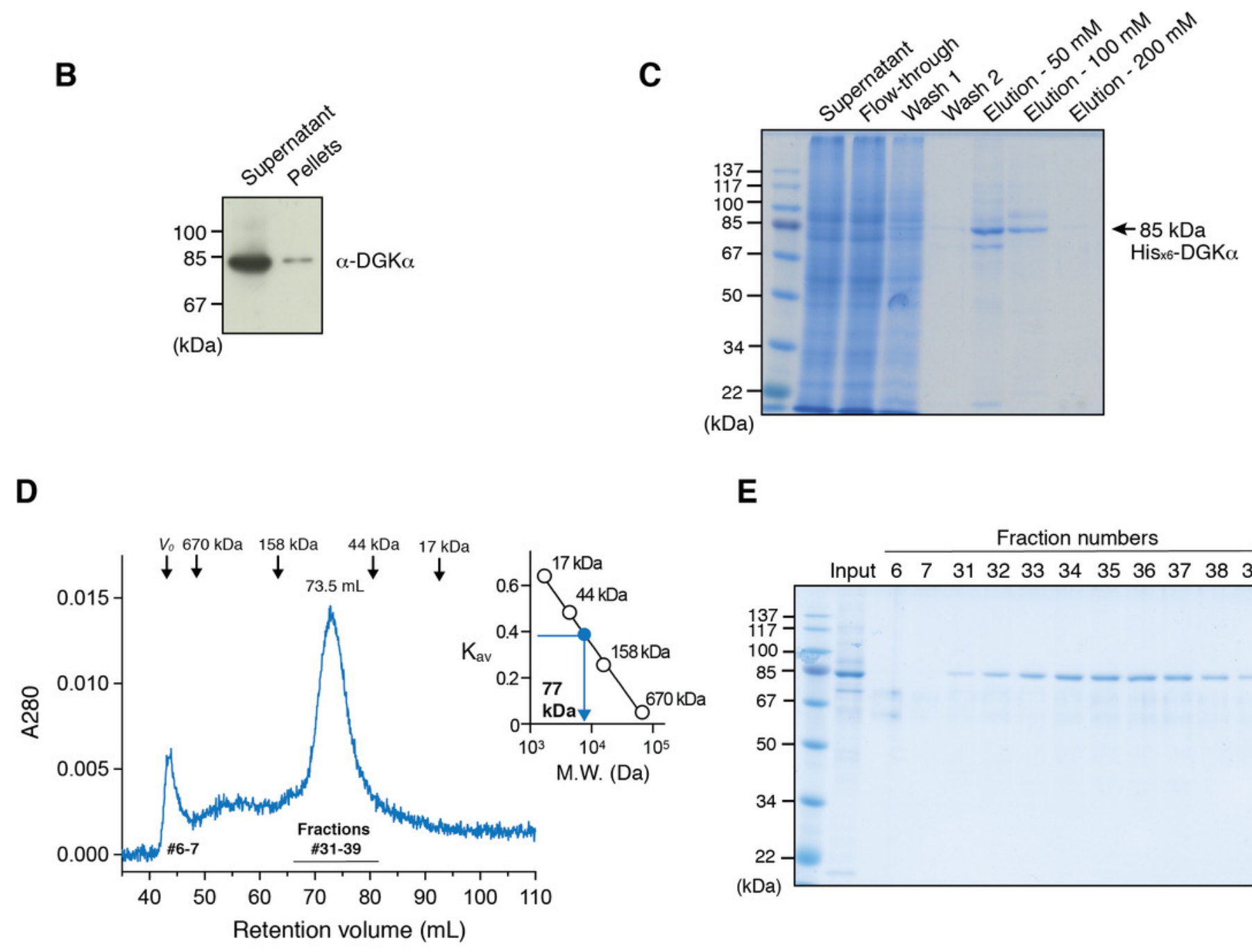

E

Fraction numbers

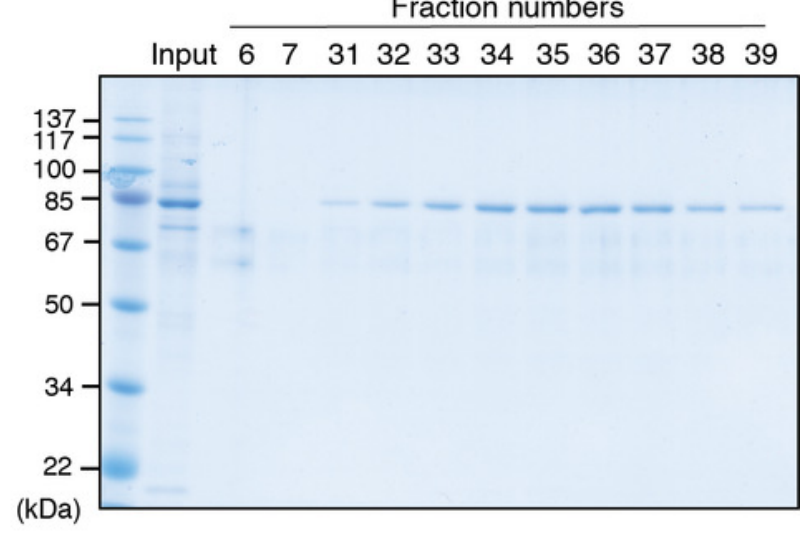




\section{Figure 2}

Purified DGK $\alpha$ is catalytically active and positively regulated by $\mathrm{Ca}^{2+}$.

(A) Luminescence-based (ADP-glo) kinase activity assay of fractions from size exclusion chromatography of DGK $\alpha$. Five microliters from each fraction containing $38.5 \mathrm{ng}$ to $363 \mathrm{ng}$ of DGK $\alpha$ was added for a reaction and the following details are described in Materials and Methods. Luminescence values are presented as relative luminescence unit (RLU) over background signals from a well containing a buffer $(20 \mathrm{mM}$ Tris- $\mathrm{HCl}, \mathrm{pH} 7.4,0.2 \mathrm{M} \mathrm{NaCl}, 3$ $\mathrm{mM} \mathrm{CaCl}_{2}, 3 \mathrm{mM} \mathrm{MgCl}, 0.5 \mathrm{mM} \mathrm{DTT}$, and $5 \%$ glycerol) used for size-exclusion chromatography. (B) Calcium-dependent activity of the purified DGK $\alpha$. The luminescencebased DGK activity assay was conducted using $150 \mathrm{ng}$ of DGK $\alpha$ in the presence of $\mathrm{CaCl}_{2}(0.6$ $\mathrm{mM}$ ) and EGTA (3.6 mM). Purified DGK $\alpha$ was pre-incubated with $3 \mathrm{mM}$ EGTA for 30 min on ice to chelate $\mathrm{CaCl}_{2}$ contained in a buffer used for size exclusion chromatography, and concentrated EGTA was also added into the reaction mixture at a final concentration of 3.6 $\mathrm{mM}$. Measured luminescence values of DGK $\alpha$ in the presence of $\mathrm{CaCl}_{2}$ or EGTA were subtracted with each negative control $\left(\mathrm{CaCl}_{2}\right.$ or EGTA) and data shown are mean \pm SD for triplicate measurements.

A

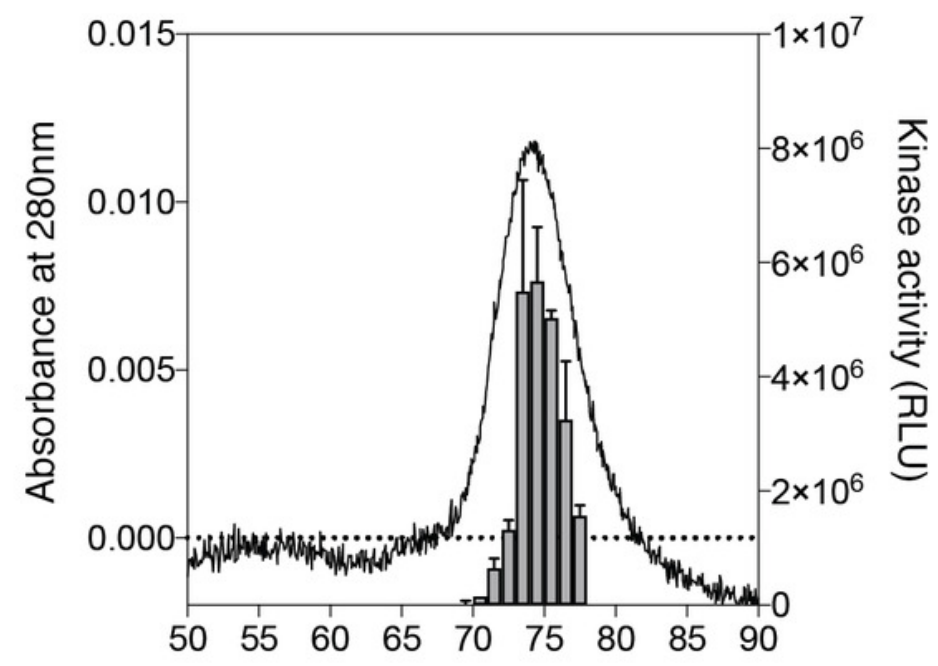

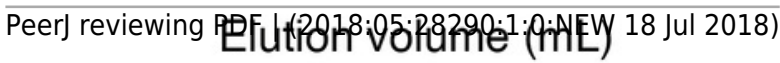

B

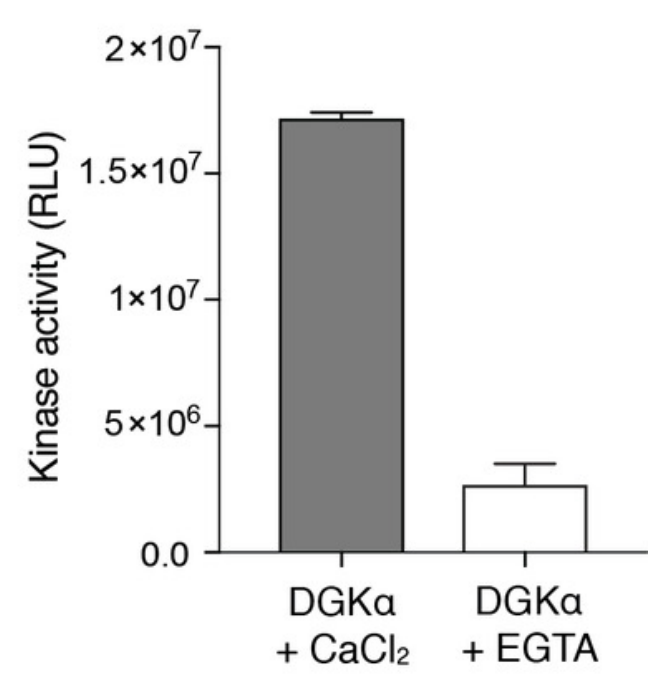




\section{Figure 3}

The enzymatic kinetics of the purified DGKa with ATP and diacylglycerol (DG).

(A) ATP dependency of DGK $\alpha$ activity was measured with the luminescence based assay. (B) DGKa activity was plotted as a function of DG concentration (mol\%). Measured luminescence values were converted into the amount of ADP produced (nmol) based on the ATP-to-ADP conversion curve separately measured with known concentration of ATP (50 $\mu \mathrm{M}$ to $1 \mathrm{mM}$ ). Data shown are mean \pm SD for triplicate measurements.

A

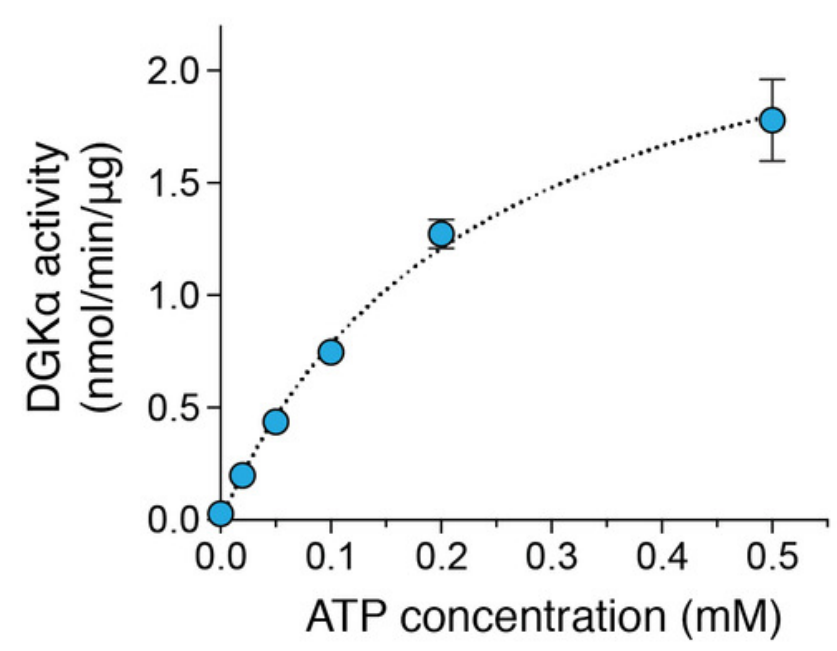

B

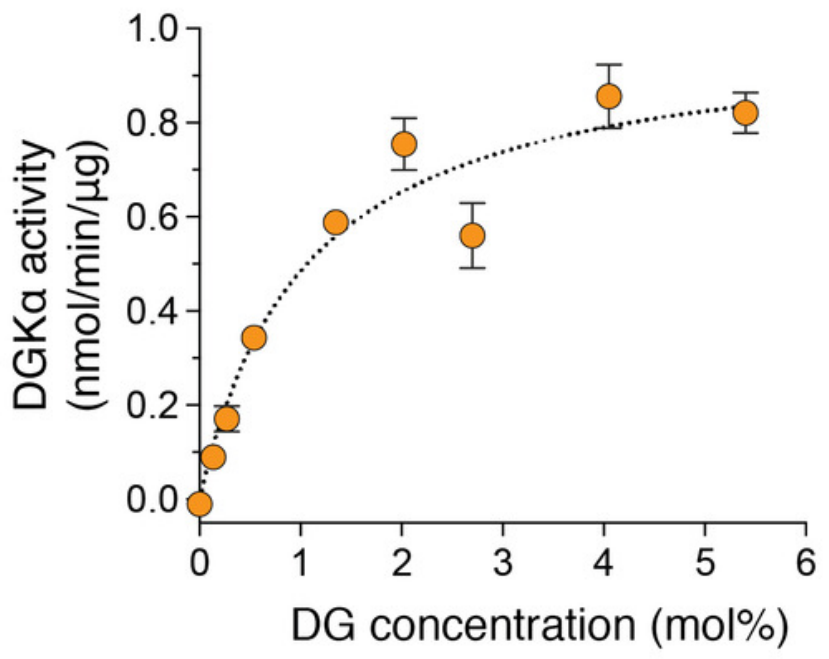




\section{Figure 4}

Inhibitory activity of a small molecule inhibitor, CU-3.

A concentration series of CU-3 ranging from 0.02 to $10 \mu \mathrm{M}$ was incubated with the purified DGK $\alpha$ (100 $\mathrm{ng}$ ) for $30 \mathrm{~min}$ at room temperature before adding to a reaction mixture for the mixed micelle/luminescence-based assay. Half maximal inhibitory concentration $\left(\mathrm{IC}_{50}\right)$ was determined by fitting the CU-3 dependent decrease of DGKa activity with the variable slope model. In the absence of DGK $\alpha$, luminescence signals with various concentrations of CU-3 were negligible and no dose-dependent changes were observed.

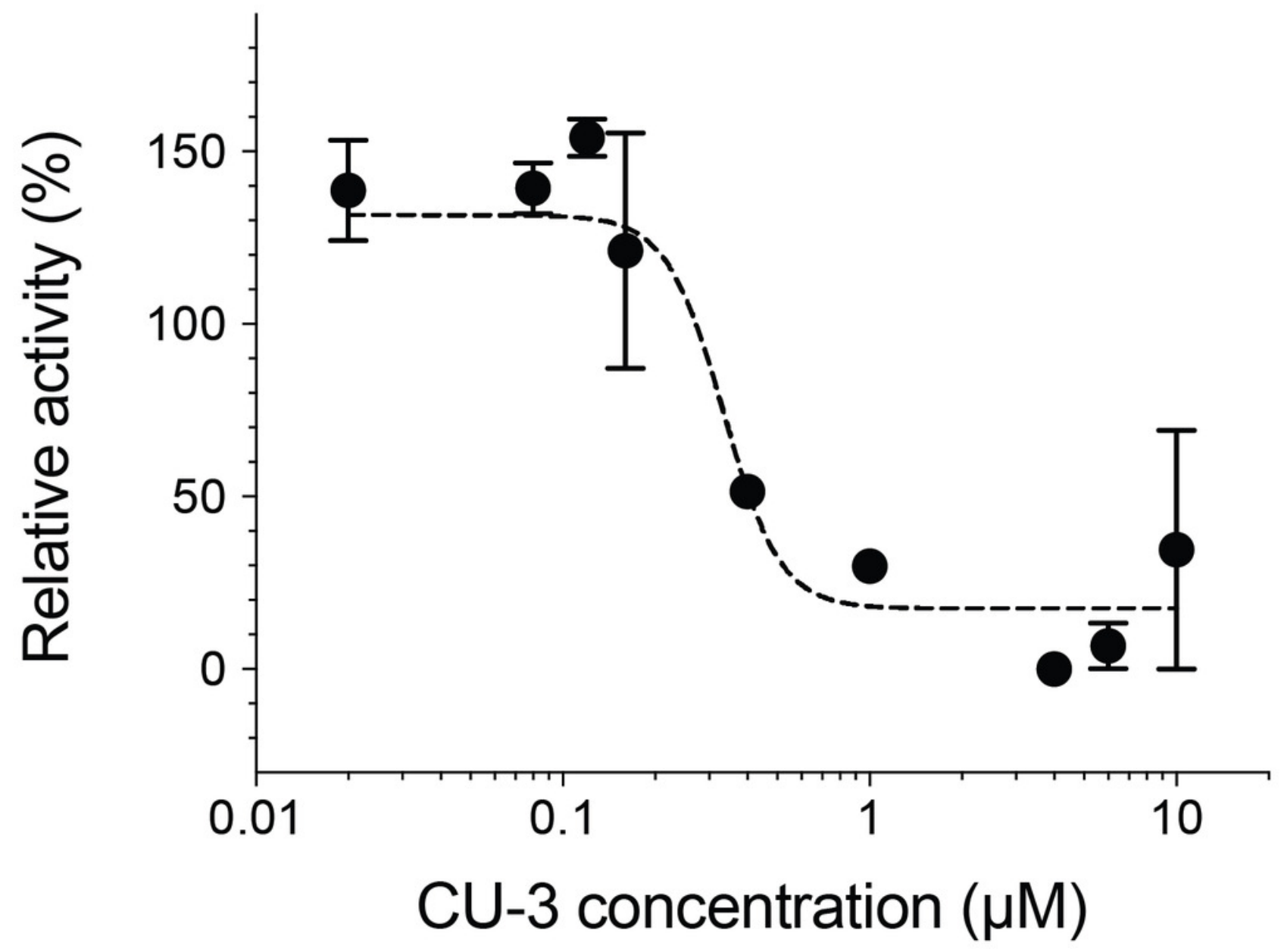




\section{Figure 5}

Secondary structure of the purified DGK $\alpha$.

CD spectrum of DGKa measured at ambient conditions between 190 and $250 \mathrm{~nm}$ on a Jasco J-805 spectrometer. DGK $\alpha$ was prepared at $0.3 \mathrm{mg} / \mathrm{mL}$ in $20 \mathrm{mM}$ Tris-HCl buffer, $\mathrm{pH}$ 7.4, 150 $\mathrm{mM} \mathrm{NaCl}, 3 \mathrm{mM} \mathrm{MgCl}_{2}, 3 \mathrm{mM} \mathrm{CaCl}, 5 \%$ glycerol. The analysis of the CD spectrum using the program Contin-LL (Provencher \& Glöckner, 1981) suited in the DICHROWEB platform (Whitmore $\&$ Wallace, 2004) showed the presence of both $\alpha$-helical (18.9\%) and b-strand (27.4\%) structures. 


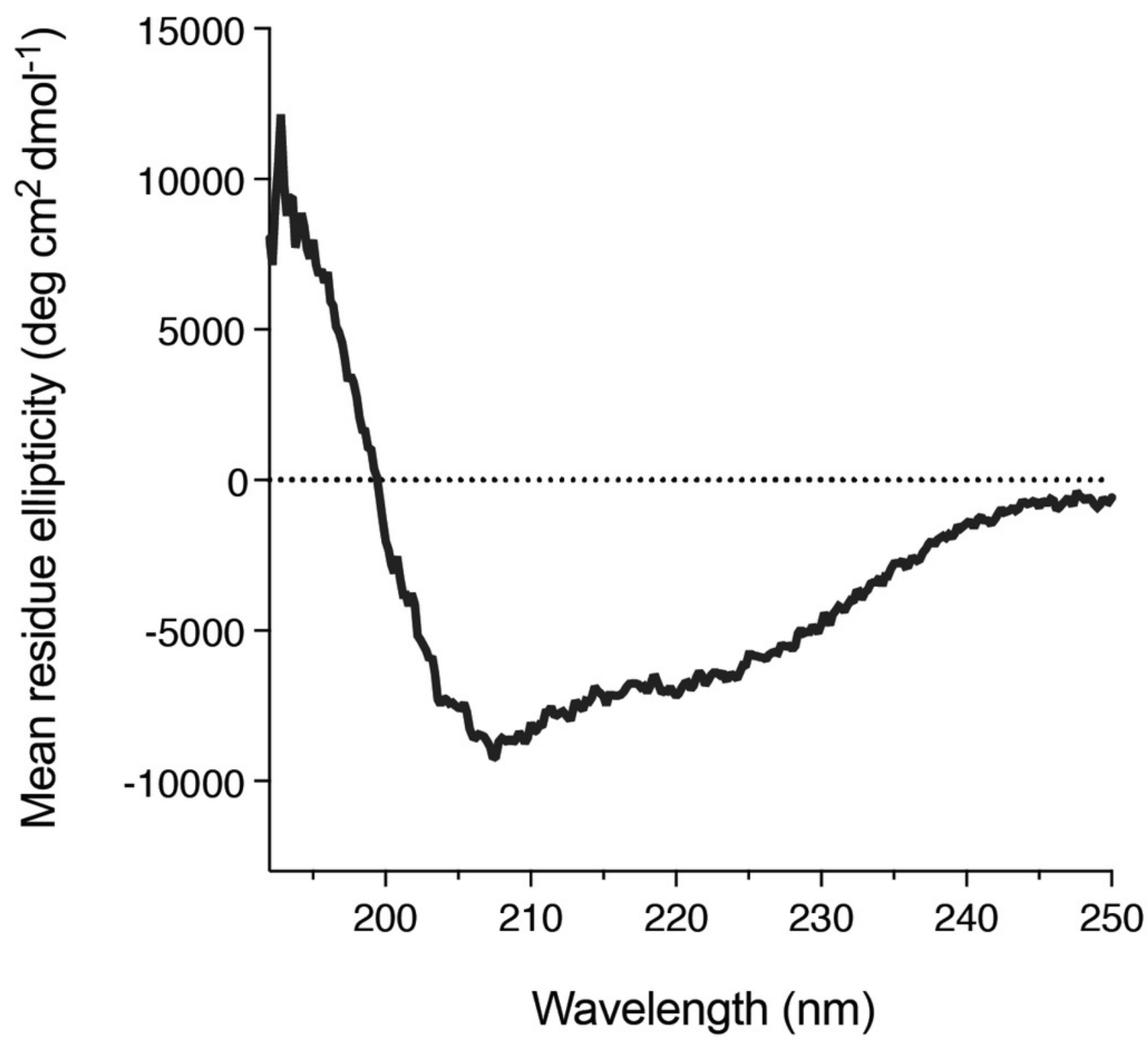

